OPEN ACCESS

Edited by:

Dirk Werling,

Royal Veterinary College, United Kingdom

Reviewed by:

Juan Pablo Jaworski, Consejo Nacional de Investigaciones

Científicas y Técnicas

(CONICET), Argentina

Kieran G. Meade,

Teagasc - The Irish Agriculture

and Food Development

Authority, Ireland

*Correspondence:

Meredith C. Frie

friemere@msu.edu

Specialty section:

This article was submitted to

Veterinary Infectious Diseases,

a section of the journal

Frontiers in Veterinary Science

Received: 02 June 2017

Accepted: 29 June 2017

Published: 14 July 2017

Citation:

Frie MC, Sporer KRB, Benitez OJ, Wallace JC, Droscha CJ, Bartlett PC and Coussens PM (2017) Dairy Cows

Naturally Infected with Bovine Leukemia Virus Exhibit Abnormal

$B$ - and T-Cell Phenotypes after

Primary and Secondary Exposures to Keyhole Limpet Hemocyanin.

Front. Vet. Sci. 4:112.

doi: 10.3389/fvets.2017.00112

\section{Dairy Cows Naturally Infected with Bovine Leukemia Virus Exhibit Abnormal B- and T-Cell Phenotypes after Primary and Secondary Exposures to Keyhole Limpet Hemocyanin}

\author{
Meredith C. Frie ${ }^{1 *}$, Kelly R. B. Sporer ${ }^{2}$, Oscar J. Benitez ${ }^{3}$, Joseph C. Wallace ${ }^{2}$, \\ Casey J. Droscha ${ }^{4}$, Paul C. Bartlett ${ }^{5}$ and Paul M. Coussens ${ }^{2}$
}

\begin{abstract}
${ }^{1}$ Cell and Molecular Biology Program, Michigan State University, East Lansing, MI, United States, ${ }^{2}$ Department of Animal Science, Michigan State University, East Lansing, MI, United States, ${ }^{3}$ Comparative Medicine and Integrative Biology Program, Michigan State University, East Lansing, MI, United States, ${ }^{4}$ NorthStar Cooperative, East Lansing, MI, United States, ${ }^{5}$ Department of Large Animal Clinical Sciences, Michigan State University, East Lansing, MI, United States
\end{abstract}

Bovine leukemia virus (BLV) is a retrovirus that is highly prevalent in US dairy herds: over $83 \%$ are BLV infected and the within-herd infection rate can be almost $50 \%$ on average. While BLV is known to cause lymphosarcomas, only $5 \%$ or fewer infected cattle will develop lymphoma; this low prevalence of cancer has historically not been a concern to dairy producers. However, more recent research has found that BLV+ cows without lymphoma produce less milk and have shorter lifespans than uninfected herdmates. It has been hypothesized that BLV infection interferes with normal immune function in infected cattle, and this could lead to reduced dairy production. To assess how naturally infected $\mathrm{BLV}^{+}$cows responded to a primary and secondary immune challenge, $10 \mathrm{BLV}^{+}$and $10 \mathrm{BLV}^{-}$cows were injected subcutaneously with keyhole limpet hemocyanin $(\mathrm{KLH})$ and dimethyldioctadecylammonium bromide. B- and T-cell responses were characterized over the following 28 days. A total of 56 days after primary KLH exposure, cows were re-injected with $\mathrm{KLH}$ and $\mathrm{B}$ - and T-cell responses were characterized again over the following 28 days. BLV+ cows produced less $\mathrm{KLH}-$ specific IgM after primary immune stimulation; demonstrated fewer CD45RO+ B cells, altered proportions of $\mathrm{CD} 55^{+} \mathrm{B}$ cells, altered expression of $\mathrm{CD} 5$ on $\mathrm{CD} 5^{+} \mathrm{B}$ cells, and reduced $\mathrm{MHCll}$ surface expression on B cells ex vivo; exhibited reduced B-cell activation in vitro; and displayed an increase in BLV proviral load after KLH exposure. In addition, $\mathrm{BLV}{ }^{+}$cows had a reduced $\mathrm{CD} 45 \mathrm{RO}^{+} \gamma \delta^{+} \mathrm{T}$-cell population in the periphery and demonstrated a greater prevalence of IL4-producing T cells in vitro. All together, our results demonstrate that both $\mathrm{B}$ - and T-cell immunities are disrupted in $\mathrm{BLV}^{+}$cows and that antigen-specific deficiencies can be detected in BLV+ cows even after a primary immune exposure.

Keywords: bovine leukemia virus, memory, $C D 5^{+}$B cells, gamma delta T cells, CD45R0, IFN $\gamma$, IL4, antibody 


\section{INTRODUCTION}

Bovine leukemia virus (BLV) is a $\delta$-retrovirus (1) that infects over $83 \%$ of dairy herds in the United States; as many as $40 \%$ of all US dairy cattle are infected (2). BLV is the causative agent of enzootic bovine leukosis (EBL), where $\mathrm{BLV}^{+}$cattle develop malignant lymphoma or leukemia (3). Although lymphoma is deadly and results in carcass condemnation at slaughter (2), it is estimated that fewer than $10 \%$ of infected cattle will eventually develop EBL (3). Unfortunately, recent research suggests that BLV infection has more negative impacts on herd health than previously appreciated.

Bovine leukemia virus infection reduces both milk production (2) and longevity (4) in infected dairy cows. While it is unclear how BLV interferes with milk production and lifespan, one hypothesis is that BLV causes immune dysregulation, which could put $\mathrm{BLV}^{+}$cattle at an increased risk for other infections. BLV most commonly infects B cells (5) and can cause persistent lymphocytosis (PL), a chronic, benign, polyclonal expansion of the B-cell compartment that occurs in $30 \%$ of infected cattle (3). In vitro experiments have demonstrated abnormalities in both innate and adaptive immune cells isolated from $\mathrm{BLV}^{+}$cattle (6). In addition, a few studies have found positive correlations between BLV and other infectious diseases $(7,8)$ and a reduction in vaccine immunity in $\mathrm{BLV}^{+}$cattle (9-11). However, when investigating immunity in naturally infected $\mathrm{BLV}^{+}$cattle, many studies were unable to control for how much antigen exposure occurred before or after BLV infection.

The current study was designed to address that specific problem. $\mathrm{BLV}^{+}$and $\mathrm{BLV}^{-}$cows were exposed to an immunostimulatory antigen, keyhole limpet hemocyanin (KLH), to mimic a primary immune response. At 56 days after primary exposure, cows were re-exposed to KLH to mimic a secondary memory immune exposure. To characterize both primary and secondary adaptive immune responses, B- and T-cell responses were tracked using ELISAs to measure antibody production against $\mathrm{KLH}$, flow cytometry to measure the dynamics of freshly isolated $\mathrm{B}$ and $\mathrm{T}$ cell subsets, and cell culture to investigate B- and T-cell responses to $\mathrm{KLH}$ and mitogenic stimulation in vitro. Specifically, CD5 and CD45R0 expressions on ex vivo B cells and CD45R0 expression on ex vivo $\mathrm{CD}^{+}, \mathrm{CD}^{+}$, and $\gamma \delta^{+} \mathrm{T}$ cells were characterized. BLV and CD25 expressions were characterized in B cells, and IFN $\gamma$ and IL4 productions were characterized in T cells after in vitro stimulation. Abnormalities in both $\mathrm{B}$ - and $\mathrm{T}$-cell subsets were detected in $\mathrm{BLV}^{+}$cattle during both primary and secondary immune responses, providing further support that BLV infection causes immune dysregulation.

\section{MATERIALS AND METHODS}

\section{Animals and KLH Inoculation}

$10 \mathrm{BLV}^{-}$and $10 \mathrm{BLV}^{+}$lactating Holstein dairy cows were enrolled in the current study (Table 1). BLV ${ }^{+}$cows (as determined by the producer's BLV milk ELISA results) were not confirmed to have PL but were selected for elevated total leukocyte counts (as determined using a Beckman Coulter counter) and an elevated
TABLE 1 | Cow enrollment characteristics.

\begin{tabular}{lll}
\hline & BLV- cows & BLV+ cows \\
\hline Age & $\begin{array}{l}\text { 4 years 11 months } \\
\text { (3 years 7 months-6 years }\end{array}$ & $\begin{array}{l}\text { 4 years11 months (3 years } \\
7 \text { months-7 years 5 months) }\end{array}$ \\
& 11 months) & \\
Days in milk & $203.5(140-350)$ & $197.7(127-293)$ \\
Lactation number & $3.3(2-5)$ & $3.2(2-5)$ \\
Reproduction status & All pregnant & All pregnant \\
\%B cell & $37.89(29.65-48.59)$ & $55.81(40.96-72.86)$ \\
Proviral load per & N/A & $95,879(62,247-123,429)$ \\
100,000 cells & &
\end{tabular}

Data are presented from d0. Data are represented as the mean and (range).

proportion of circulating B cells [as determined by immunostaining for surface IgM (SIgM) on freshly isolated PBMCs] 1 week prior to the study's initiation. $\mathrm{BLV}^{+}$cows had a high proviral load (PVL) on d0 (12). BLV ${ }^{-}$cows were then age and lactation matched to the 10 selected $\mathrm{BLV}^{+}$cows. Both $\mathrm{BLV}^{-}$and $\mathrm{BLV}^{+}$ cows were also re-screened for BLV infection using a commercial serum ELISA (NorthStar Cooperative) 1 week prior to the study start. BLV serum ELISAs and endpoint PCR (on DNA extracted from whole blood) to detect BLV provirus were also used on samples collected on the first and last days of the study to confirm $\mathrm{BLV}$ status. One $\mathrm{BLV}^{-}$cow seroconverted in between enrollment diagnostics and the start of the study; this cow and her matched $\mathrm{BLV}^{+}$cow were excluded from the final data analysis.

Upon study initiation on day 0 (d0), all cows received the primary $\mathrm{KLH}$ inoculation consisting of $1.5 \mathrm{~mL} \mathrm{KLH}$ cocktail injected subcutaneously into the left side of the neck. The KLH cocktail was composed of $200 \mu \mathrm{gLH}$ (Sigma) in $0.75 \mathrm{~mL} 1 \times$ phosphate-buffered saline (PBS) containing 5\% bovine serum albumin and $0.75 \mathrm{~mL} 20 \mathrm{mg} / \mathrm{mL}$ adjuvant dimethyldioctadecylammonium bromide (DDA) (Sigma) in $1 \times$ PBS (13). On d56, cows received the secondary KLH inoculation with $1.5 \mathrm{~mL}$ KLH cocktail subcutaneously injected into the right side of the neck. All protocols were reviewed and approved by the Michigan State University Institutional Animal Use and Care Committee (AUF\# 04/15-061-00).

\section{Whole Blood, Plasma, and PBMC Isolation}

Whole blood was collected by coccygeal venipuncture on $\mathrm{d} 0$ before primary inoculation and on days $7,14,18,21,28,54$, and 56 after primary inoculation; after blood collection on $\mathrm{d} 56$, the secondary KLH inoculation was administered and blood was collected on days $60,67,70,77$, and 84 after primary inoculation (days 4, 11, 14, 21, and 28 after secondary inoculation). Blood for PVL quantification was collected in Vacutainer blood collection tubes containing the anticoagulant EDTA (Becton Dickinson); $1 \mathrm{~mL}$ aliquots of whole blood were stored at $-80^{\circ} \mathrm{C}$. Blood for antibody quantification and PBMC immunostaining was collected in Vacutainer blood collection tubes containing the anticoagulant ACD (Becton Dickinson). Plasma and PBMCs were isolated as previously described (10). Briefly, aliquots of plasma with $0.1 \%$ sodium azide were stored at $-80^{\circ} \mathrm{C}$ and PBMCs were isolated using Percoll density centrifugation. 


\section{BLV PVL Quantification}

DNA was extracted from whole blood using the DNeasy Blood and Tissue kit (Qiagen) using a modified protocol. Briefly, $200 \mu \mathrm{L}$ of whole blood, $40 \mu \mathrm{L}$ of proteinase $\mathrm{K}, 218 \mu \mathrm{L}$ of buffer $\mathrm{AL}$ and $218 \mu \mathrm{L}$ of $100 \%$ ethanol were used instead of the recommended kit volumes. Extracted DNA was quantified using a Nanodrop-1000, and A260/280 ratios were used to assess sample purity. DNA was diluted to $30 \mathrm{ng} / \mu \mathrm{L}$ in elution buffer for PVL quantification. BLV PVL was determined using the Coordination of Common Motifs-qPCR to amplify the long terminal repeat (LTR) of the BLV provirus. To normalize genomic DNA input, the single-copy Bola-DRA gene was also amplified (14). In brief, $30 \mathrm{ng}$ of genomic DNA were assayed using TaqMan Gene Expression Master Mix (Applied Biosystems, CA, USA) on the 7500 FAST Real-time PCR System (Applied Biosystems, CA, USA). BLV copy number and BoLA-DRA copy number were calculated using 10-1 $\times 10^{5}$ copies of the standard plasmid, which contained a copy of BLV-LTR and BoLA-DRA. Each value was calculated using the algorithm suggested by the manufacturer. PVL was the ratio of BLV copy number to BoLA-DRA copy number multiplied by 100,000 (15). PVL was expressed as BLV copy number/100,000 cells.

\section{Anti-KLH Antibody Quantification}

Anti-KLH antibodies were quantified from plasma collected on days $0,7,14,21,28,56,60,67,70,77$, and 84 after primary inoculation. Flat-bottomed 96-well ELISA plates (Thermo Fisher Scientific) were incubated with $100 \mu \mathrm{L}$ of $1 \mu \mathrm{g} / \mathrm{mL} \mathrm{KLH}$ in $50 \mathrm{mM}$ carbonate/bicarbonate buffer overnight at $4^{\circ} \mathrm{C}$. Plates were washed $3 \times$ with wash buffer $(0.05 \%$ Tween- 20 in $1 \times$ PBS) and blocked with $2 \%$ heat-inactivated horse serum in wash buffer for $1 \mathrm{~h}$ at $37^{\circ} \mathrm{C}$. Plates were then washed $5 \times$, and $100 \mu \mathrm{L}$ of plasma (diluted 1:50 in blocking buffer) was added to wells and incubated for $1 \mathrm{~h}$ at room temperature. Plates were washed $5 \times$ and then incubated for $1 \mathrm{~h}$ at room temperature with $100 \mu \mathrm{L}$ antibovine IgM, IgG1, or IgG2 conjugated to horseradish peroxidase (Thermo Fisher Scientific) diluted 1:10,000 in blocking buffer as previously described (10). Plates were washed $5 \times$ and incubated for $15 \mathrm{~min}$ at room temperature in the dark with $100 \mu \mathrm{L} \mathrm{TMB}$ substrate (Sigma). A total of $100 \mu \mathrm{L}$ stop solution $\left(2 \mathrm{M} \mathrm{H}_{2} \mathrm{SO}_{4}\right)$ was added, and the optical density was measured at $450 \mathrm{~nm}$ using a SpectraMax M5 microplate reader. All samples were run in duplicate, and each plate included blank and naive (not exposed to $\mathrm{KLH}$ ) controls.

\section{Immunostaining of Freshly Isolated PBMCs}

Immunostaining of freshly isolated PBMCs was performed as previously described (10) on days $0,7,14,21,28,56,60,67,70$, and 77 after primary inoculation. Briefly, $5 \times 10^{5}$ PBMCs were fixed in $4 \%$ paraformaldehyde and then labeled via indirect immunofluorescence first with mouse anti-bovine primary antibodies and second with goat anti-mouse secondary antibodies. The freshly isolated B-cell population was characterized using the stain labeled "fresh B" in Table 2, and the freshly isolated T-cell population was characterized using the stain labeled "fresh $\mathrm{T}$ " in Table 2.
TABLE 2 | Antibodies used for immunostaining experiments.

\begin{tabular}{|c|c|c|c|c|}
\hline Stain & $\begin{array}{l}1^{\circ} \mathrm{MAb} \\
\text { target }\end{array}$ & Target phenotype & Clone & $2^{\circ} \mathrm{Ab}$ target \\
\hline \multirow[t]{4}{*}{ Fresh B } & CD45R0 & $\begin{array}{l}\text { Effector/memory } \\
\text { lymphocytes }\end{array}$ & ILA116A & IgG3 AF88 \\
\hline & $\mathrm{MHCll}$ & Antigen presentation & TH16A & IgG2a PE \\
\hline & $\begin{array}{l}\text { Surface lgM } \\
\text { (SlgM) }\end{array}$ & B cells & PIG45A & IgG2b PE-Cy7 \\
\hline & CD5 & $\mathrm{CD}^{+} \mathrm{B}$ cells & CACT105A & $\operatorname{lgG} 1 \mathrm{AF} 647$ \\
\hline \multirow[t]{4}{*}{ Fresh $\mathrm{T}$} & CD45R0 & $\begin{array}{l}\text { Effector/memory } \\
\text { lymphocytes }\end{array}$ & ILA116A & IgG3 AF88 \\
\hline & CD4 & Helper T cells & IL11A & IgG2a PE \\
\hline & CD8 & Cytotoxic T cells & BAQ111A & IgM PE-Cy7 \\
\hline & $\gamma \delta \mathrm{TcR}$ & Gamma delta T cells & GB21A & IgG2b AF647 \\
\hline \multirow[t]{4}{*}{$\mathrm{IFN} \gamma$} & $\gamma \delta \mathrm{TcR}$ & Gamma delta T cells & GB21A & IgG2b AF88 \\
\hline & CD4 & Helper T cells & IL11A & IgG2a PE \\
\hline & CD8 & Cytotoxic T cells & BAQ111A & IgM PE-Cy7 \\
\hline & $\mathrm{IFN} \gamma^{\mathrm{a}}$ & Th1 cytokine & CC302 & $\operatorname{lgG} 1 \mathrm{AF} 647^{\mathrm{a}}$ \\
\hline \multirow[t]{4}{*}{ IL4 } & $\gamma \delta \mathrm{TCR}$ & Gamma delta T cells & GB21A & IgG2b AF88 \\
\hline & CD4 & Helper T cells & CACT138A & IgG1 PE \\
\hline & CD8 & Cytotoxic T cells & BAQ111A & IgM PE-Cy7 \\
\hline & $\operatorname{IL} 4^{\mathrm{a}}$ & Th2 cytokine & CC303 & $\operatorname{lgG} 2 \mathrm{a} A F 647^{\mathrm{a}}$ \\
\hline \multirow[t]{4}{*}{ CD45R0 } & CD45R0 & $\begin{array}{l}\text { Effector/memory } \\
\text { Iymphocytes }\end{array}$ & ILA116A & IgG3 AF88 \\
\hline & $\mathrm{MHCll}$ & Antigen presentation & TH16A & IgG2a PE \\
\hline & SlgM & B cells & PIG45A & IgG2b PE-Cy7 \\
\hline & $\begin{array}{l}\text { Bovine } \\
\text { leukemia virus } \\
\text { (BLV) gp } 51^{\mathrm{a}}\end{array}$ & BLV-expressing B cells & & $\operatorname{lgG} 1 \mathrm{AF647^{ \textrm {a } }}$ \\
\hline \multirow[t]{4}{*}{ CD25 } & CD25 & IL2 receptor, $\alpha$ chain & LCTB2A & IgG3 AF88 \\
\hline & $\mathrm{MHCll}$ & Antigen presentation & TH16A & IgG2a PE \\
\hline & SlgM & B cells & PIG45A & IgG2b PE-Cy7 \\
\hline & BLV gp51a & BLV-expressing B cells & & $\operatorname{lgG} 1 \mathrm{AF} 647^{\mathrm{a}}$ \\
\hline
\end{tabular}

All primary MAbs were purchased from Washington State University Monoclonal Antibody Center except IFNy and IL4 (Bio-Rad) and BLV gp51 NMRD). All secondary antibodies were purchased from Thermo Fisher Scientific except IgM PE-Cy7 (eBioscience) and IgG2b PE-Cy7 (Abcam).

${ }^{a}$ Antibodies used for intracellular labeling.

\section{In Vitro Stimulation of PBMCs}

To investigate T-cell activation, $2 \times 10^{6} \mathrm{PBMCs}$ were cultured at $38^{\circ} \mathrm{C}$ and $5 \% \mathrm{CO}_{2}$ in $1 \mathrm{~mL}$ Roswell Park Memorial Institute (RPMI) complete media (RPMI plus 10\% fetal bovine serum, $1 \%$ penicillin/ streptomycin, and $1 \%$ fungizone, $\mathrm{pH} 7.4$ ) in 24-well culture plates (Corning). PBMCs were either cultured in medium alone (NIL) for $18 \mathrm{~h}$, with $200 \mu \mathrm{g} / \mathrm{mL} \mathrm{KLH}$ for $18 \mathrm{~h}$, or with $20 \mu \mathrm{g} / \mathrm{mL}$ positive control concanavalin A (CONA) for the final $6 \mathrm{~h}$. All samples were treated with $20 \mathrm{ng} / \mathrm{mL}$ brefeldin A at $12 \mathrm{~h}$ to prevent cytokine secretion. T-cell activation was measured on days $7,14,56,67$, and 77.

To investigate $\mathrm{B}$-cell activation, $5 \times 10^{6} \mathrm{PBMCs}$ were cultured at $38^{\circ} \mathrm{C}$ and $5 \% \mathrm{CO}_{2}$ in $3 \mathrm{~mL}$ RPMI complete media in 12-well culture plates (Corning) with medium alone (NIL), $200 \mu \mathrm{g} / \mathrm{mL}$ $\mathrm{KLH}$, or with positive control $20 \mathrm{ng} / \mathrm{mL}$ phorbol 12-myristate 13 -acetate and $400 \mathrm{ng} / \mathrm{mL}$ ionomycin (P/I) for $18 \mathrm{~h}$. B-cell activation was measured on days 18,54 , and 70 .

\section{Immunostaining of Cultured PBMCs}

PBMCs were labeled with four-color stains to investigate IFN $\gamma$ production by $\mathrm{T}$ cells ("IFN $\gamma$ " in Table 2), IL4 production 
by T cells ("IL4" in Table 2), and BLV expression in B cells ("CD45R0" and "CD25" in Table 2). Immunostaining of cultured PBMCs was performed as previously described (10). Briefly, indirect immunostaining for surface receptors on live PBMCs was done as described for freshly isolated PBMCs. PBMCs were then fixed and permeabilized using a fixation/permeabilization kit according to manufacturer's instructions (eBioscience), and PBMCs were labeled with a primary mouse anti-bovine or antiBLV monoclonal antibody and subsequently labeled with a goat anti-mouse secondary antibody. Labeled PBMCs were stored at $4^{\circ} \mathrm{C}$ overnight until flow cytometry analysis.

\section{Immunostaining Analysis}

Data were acquired using an Accuri C6 flow cytometer equipped with CSampler (Becton Dickinson). Data were compensated using the Accuri C6 software (Becton Dickinson) and then exported for analysis using FCS Express 4 (De Novo Software). PBMCs were initially selected using forward and side scatter gating to exclude debris, and cells were identified gating on lineage-specific markers (CD4, CD8, $\gamma \delta$, or SIgM). Expression of IFN $\gamma$, IL4, CD45R0, MHCII, CD5, and CD25 were then subsequently characterized within specific cell types, and marker expression was expressed as either the mean relative percent or the mean fluorescence intensity (MFI). Unless noted, all referenced B cells are $\mathrm{SIgM}^{+} \mathrm{MHCII}^{+}$. CD5 labeling on fresh PBMCs exhibited three populations; the center population was denoted "CD5 dim" and the far right population was denoted

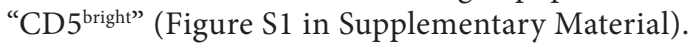

\section{Statistics}

Statistical analysis was performed using SAS 9.4 (SAS Institute). Antibody and fresh PBMC data were analyzed using repeated measures ANOVA with BLV and time as fixed effects and post hoc Bonferroni correction for pairwise comparisons. Cultured PBMC data were analyzed using repeated measures ANOVA with BLV and stimulant as fixed effects and post hoc Bonferroni correction for pairwise comparisons. A Tukey test was used to analyze the difference in MHCII or CD25 MFIs between different B-cell subsets. Outliers were detected using Grubbs test; both outliers and their matched cow were eliminated from analysis. Significance was determined as $p<0.05$.

\section{RESULTS}

\section{BLV+ Cows Exhibit Reduced IgM Production In Vivo}

To characterize the strength of the humoral immune response in $\mathrm{BLV}^{+}$cows, the relative quantities of KLH-specific IgM, IgG1, and IgG2 were measured. As expected, both $\mathrm{BLV}^{+}$and $\mathrm{BLV}^{-}$ cows produced KLH-specific IgM, IgG1, and IgG2 after primary and secondary KLH inoculations ( $p<0.001$ for all isotypes). Interestingly, $\mathrm{BLV}^{+}$cows had less $\operatorname{IgM}(p=0.0045)$ after primary $\mathrm{KLH}$ inoculation at all time points, including $\mathrm{d} 0$. However, $\mathrm{BLV}^{+}$ cows made IgM at levels equal to $\mathrm{BLV}^{-}$cows after the secondary $\mathrm{KLH}$ inoculation $(p=0.7742$ ) (Figure 1A). In contrast to IgM production, $\mathrm{BLV}^{+}$and $\mathrm{BLV}^{-}$cows produced equivalent levels of $\operatorname{IgG1}(p=0.6715)$ (Figure 1B) and IgG2 $(p=0.9437)$ (Figure 1C) after both primary and secondary KLH inoculations. These data support recent evidence that BLV infection interferes with $\operatorname{IgM}$ antibody production after both a primary immune challenge and a common vaccine booster injection (10).

\section{BLV + Cows Demonstrate Abnormal Circulating B-Cell Populations In Vivo}

To investigate how circulating B-cell populations changed in response to immune stimulation, freshly isolated PBMCs were immunostained to examine both CD45R0 and CD5 B-cell populations in $\mathrm{BLV}^{+}$and $\mathrm{BLV}^{-}$cows. Unless noted in the text, all B cells are $\mathrm{SIgM}^{+} \mathrm{MHCII}^{+}$. Surprisingly, the $\mathrm{SIgM}^{+}$B-cell population from $\mathrm{BLV}^{+}$cows did steadily increase over time $(p<0.05)$ after both primary and secondary KLH inoculations; however, this trend was not observed in $\mathrm{BLV}^{-}$cows. As expected, $\mathrm{BLV}^{+}$ cows had significantly more circulating B cells than uninfected, age-matched cows $(p<0.0001)$ (Figure 2C). Some B-cell populations did not shift in response to $\mathrm{KLH}$ inoculation: in both $\mathrm{BLV}^{+}$ and $\mathrm{BLV}^{-}$cows, the mean relative percent of $\mathrm{MHCII}^{+} \mathrm{SIgM}^{+}$ $\mathrm{B}$ cells and CD45R0+ B cells, as well as the CD5 MFI on B cells, all remained constant. However, these populations were altered in $\mathrm{BLV}^{+}$cows. While $\mathrm{BLV}^{+}$cows exhibited a higher proportion of $\mathrm{MHCII}^{+} \mathrm{SIgM}^{+} \mathrm{B}$ cells $(p=0.0084)$, they also demonstrated a large reduction in $\mathrm{CD} 45 \mathrm{R} 0^{+} \mathrm{B}$ cells compared to uninfected, age-matched controls $(p<0.0001)$ (Figure 2A). When analyzing CD5 expression on $\mathrm{B}$ cells, two distinct positive populations

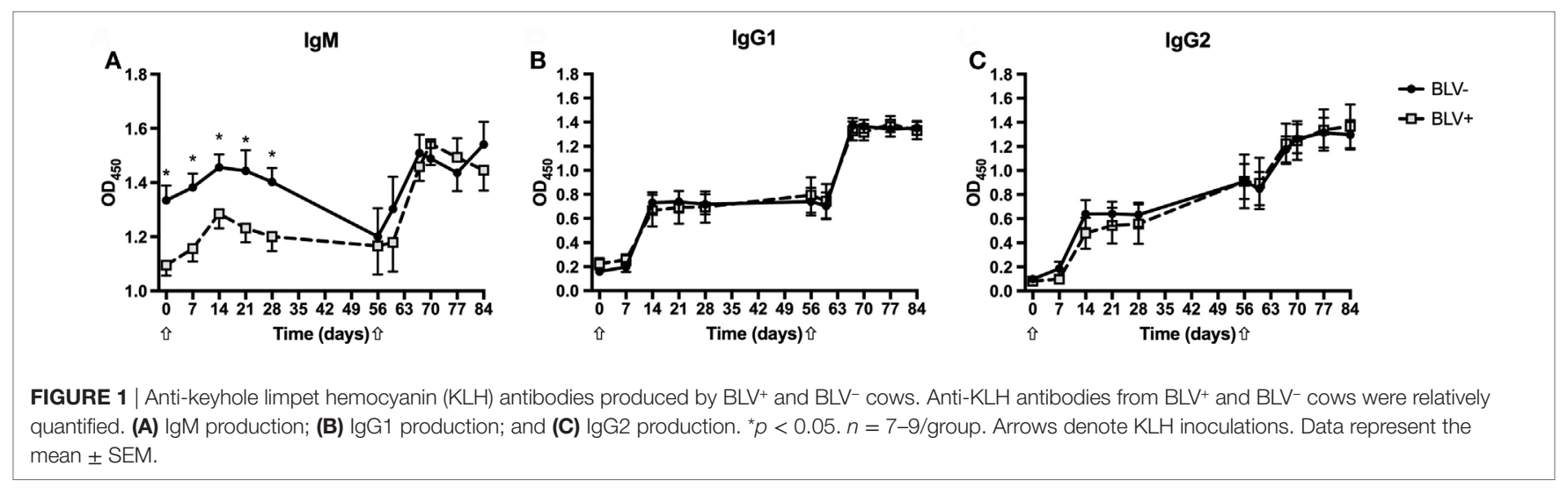



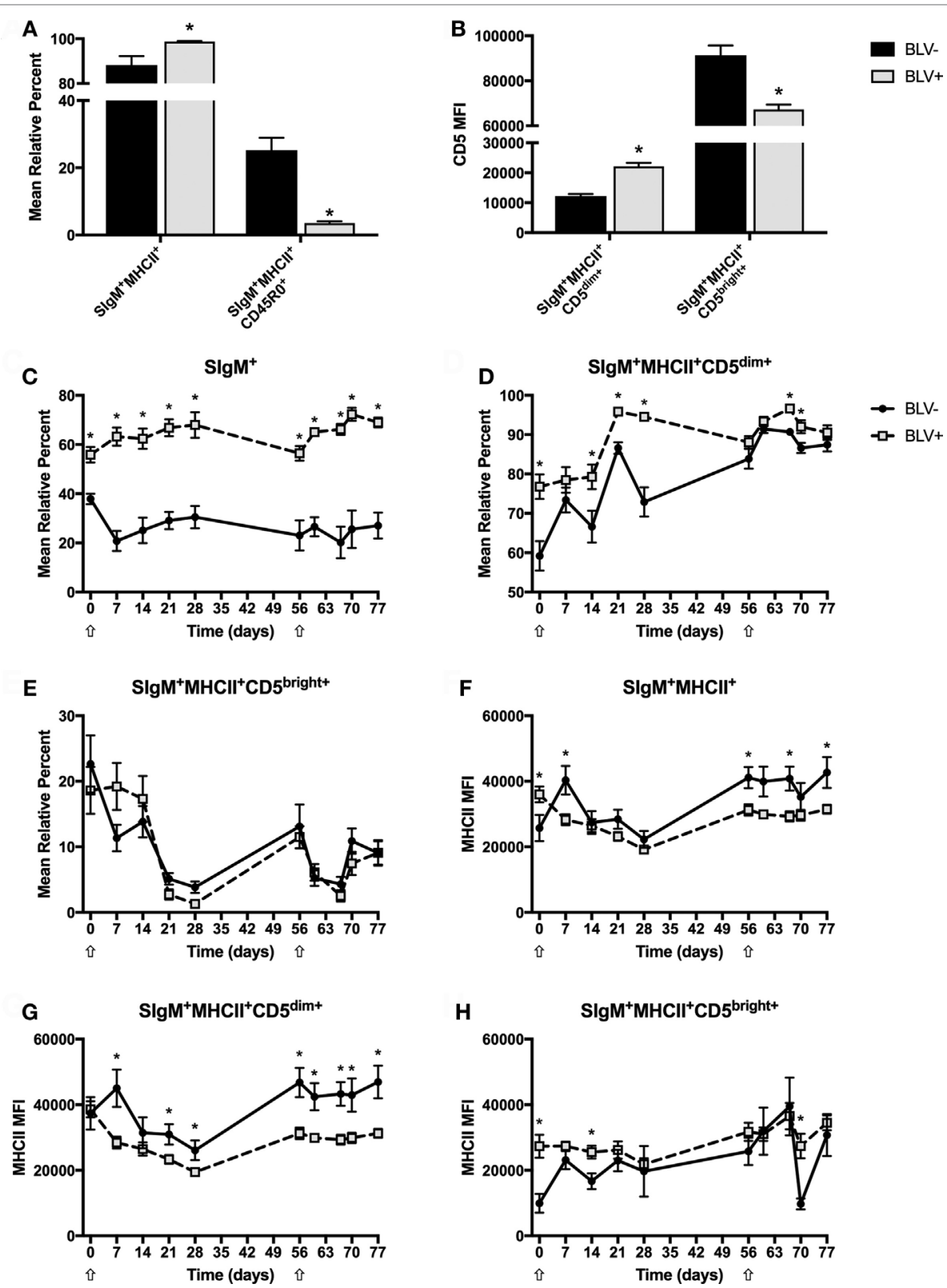

FIGURE 2 | Circulating B-cell populations in BLV+ and BLV- cows. Freshly isolated PBMCs from BLV ${ }^{+}$and BLV- cows were immunostained to characterize the circulating B-cell population. (A) Mean relative percentages of B-cell populations on d0. (B) Mean fluorescence intensities (MFls) of B-cell populations on d0.

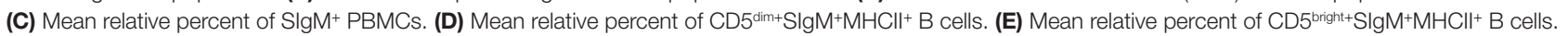

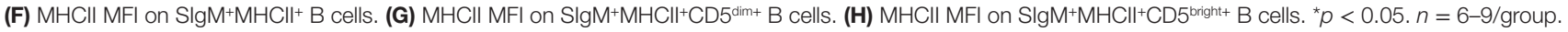
Arrows denote keyhole limpet hemocyanin inoculations. Data represent the mean \pm SEM.

were observed, which we denoted $\mathrm{CD} 5^{\mathrm{dim}}$ and $\mathrm{CD} 5^{\text {bright }}$ (Figure $\mathrm{S} 1$ in Supplementary Material). Interestingly, B cells from BLV ${ }^{+}$ cows had higher CD5 expression on CD $5^{\mathrm{dim}+} \mathrm{B}$ cells $(p=0.0002)$ but lower CD5 expression on CD $5^{\text {bright+ }} \mathrm{B}$ cells $(p=0.0017)$ (Figure 2B).

Although the surface expression of CD5 did not change over time, both $\mathrm{CD} 5^{\mathrm{dim}+}$ and $\mathrm{CD} 5^{\text {bright+ }} \mathrm{B}$-cell populations responded to KLH inoculation $(p<0.05)$; while the $C D 5^{\mathrm{dim}+} \mathrm{B}$-cell population steadily increased after inoculation, the $\mathrm{CD} 5^{\text {bright+ }} \mathrm{B}$-cell population sharply declined. In addition, $\mathrm{BLV}^{+}$cows displayed a lower $\mathrm{CD} 5^{\mathrm{dim}+} \mathrm{B}$-cell population $(p=0.0043)$ (Figure 2D), but the $\mathrm{CD} 5^{\text {bright+ }} \mathrm{B}$-cell population was equal between $\mathrm{BLV}^{+}$and $\mathrm{BLV}^{-}$cows $(p=0.9611)$ (Figure $\left.2 \mathrm{E}\right)$.

We were also interested in the effect of BLV infection on MHCII surface expression. Surprisingly, MHCII surface expression actually fluctuated in response to KLH exposure on all measured B-cell types $(p<0.05)$. BLV ${ }^{+}$cows presented lower MHCII surface expression on CD $5^{\mathrm{dim}+} \mathrm{B}$ cells $(p=0.0168)$ (Figure 2G) 
and a trending lower MHCII surface expression on all B cells $\left(p=0.0722\right.$ ) (Figure $2 \mathbf{F}$ ). In contrast, $\mathrm{BLV}^{+}$and $\mathrm{BLV}^{-}$cows exhibited equivalent MHCII surface expression on CD45R0 ${ }^{+}$ $(p=0.7919)$ (data not shown) and CD $5^{\text {bright+ }} \mathrm{B}$ cells $(p=0.5662)$ (Figure 2H).

\section{B Cells from BLV+ Cows Develop Atypical Phenotypes after In Vitro Stimulation}

To determine if KLH stimulation in vitro induced BLV expression in infected B cells, PBMCs were cultured in the presence of KLH or P/I-positive control stimulation and BLV expression (by immunostaining for viral protein BLV gp51) and B-cell activation (by immunostaining for CD25) were characterized. While B-cell culture was done on $\mathrm{d} 18,54$, and 70 , there was no difference in results from different time points. Thus, results presented are from $\mathrm{d} 70$.

There was no overall difference between $\mathrm{BLV}^{+}$and $\mathrm{BLV}^{-}$cows when comparing the mean relative percent of $\mathrm{CD}_{2} 5^{+} \mathrm{B}$ cells $(p=0.5849)$, and both KLH and P/I stimulation increased the proportion of $\mathrm{CD}_{2} 5^{+} \mathrm{B}$ cells. However, B cells from $\mathrm{BLV}^{+}$cows exhibited only a trending $(p=0.053)$ rise in $\mathrm{CD} 25^{+} \mathrm{B}$ cells after $\mathrm{KLH}$ stimulation; in fact, the proportion of $\mathrm{CD}_{2} 5^{+} \mathrm{B}$ cells in $\mathrm{KLH}$-stimulated cultures from $\mathrm{BLV}^{+}$cows was significantly lower than $\mathrm{KLH}$-stimulated cultures from $\mathrm{BLV}^{-}$cows (Figure $3 \mathrm{~A}$ ).

In contrast to the mean relative percent of activated $\mathrm{B}$ cells, the surface expression of CD25 on B cells was significantly affected by BLV status $(p=0.0044)$. Only B cells from BLV ${ }^{-}$cows demonstrated higher CD25 MFI after P/I stimulation; B cells from $\mathrm{BLV}^{+}$cows actually decreased CD25 surface expression after KLH stimulation, and the surface expression of CD25 was lower on $\mathrm{B}$ cells from $\mathrm{BLV}^{+}$cows, in comparison to $\mathrm{B}$ cells from $\mathrm{BLV}^{-}$cows, after both $\mathrm{KLH}$ and P/I stimulation (Figure 3B).

PBMCs were also cultured to investigate if KLH stimulation could induce BLV expression in B-cell populations from BLV ${ }^{+}$ cows. KLH failed to trigger BLV expression in any measured B-cell subset. Surprisingly, KLH stimulation actually reduced the proportion of $\mathrm{BLV}$-expressing $\mathrm{CD} 45 \mathrm{R}^{+} \mathrm{B}$ cells. However, CD45R0 expression on $\mathrm{B}$ cells did not have a significant effect on BLV expression overall ( $p=0.8236$ ) (Figure 4A). In contrast, CD25 expression on $\mathrm{B}$ cells did have a significant effect on BLV expression $(p=0.0013) ; \mathrm{CD}^{2} 5^{+} \mathrm{B}$ cells under all culture conditions exhibited a much greater proportion of BLV expression in comparison to CD25 $5^{-}$B cells (Figure 4B).

We also explored how BLV expression affected B-cell phenotypes in vitro. When comparing B cells from $\mathrm{BLV}^{-}$cows to $\mathrm{B}$ cells from $\mathrm{BLV}^{+}$cows that did $\left(\mathrm{BLV}^{+}\right)$or did not $\left(\mathrm{BLV}^{-}\right)$express $\mathrm{BLV}$ protein gp51, BLV ${ }^{+} \mathrm{B}$ cells expressed much higher MHCII in all culture conditions in comparison to both $\mathrm{BLV}^{-} \mathrm{B}$ cells and $\mathrm{B}$ cells from $\mathrm{BLV}^{-}$cows (Figure 4C). When investigating the effect of BLV expression on CD25 surface expression, CD25 MFI increased in P/I-stimulated cultures as expected, but only on B cells from $\mathrm{BLV}^{-}$cows and $\mathrm{BLV}^{+} \mathrm{B}$ cells from $\mathrm{BLV}^{+}$cows; $\mathrm{BLV}^{-} \mathrm{B}$ cells from $\mathrm{BLV}^{+}$cows failed to increase the CD25 MFI (Figure 4D). Taken together, these results suggest that $\mathrm{B}$ cells from $\mathrm{BLV}^{+}$cows are less reactive to in vitro stimulation than $\mathrm{B}$ cells from $\mathrm{BLV}^{-}$cows; $\mathrm{BLV}$ expression in vitro is more prevalent in activated B cells; and $\mathrm{B}$ cells from $\mathrm{BLV}^{+}$cows demonstrate different phenotypes in comparison to $\mathrm{B}$ cells from $\mathrm{BLV}^{-}$cows, both in $\mathrm{BLV}^{-}$and $\mathrm{BLV}^{+}$ B-cell subsets.

\section{BLV PVL In Vivo Increases after KLH Inoculation}

In order to assess how the BLV PVL changed over time after KLH+ DDA exposure, DNA was extracted from whole blood from $\mathrm{BLV}^{+}$ cattle and qPCR was used to measure PVL. The average BLV PVL on d0 before inoculation was almost 96,000 copies $/ 10^{5}$ cells; after both primary and secondary KLH inoculations, the PVL sequentially increased over time $(p<0.0001)$ (Figure 5). BLV ${ }^{+}$cows exhibited the largest increase in PVL on the final day of collection (28 days post-exposure for primary and 21 days post-exposure for secondary); in both cases, the PVL increased by over 18,000 copies $/ 10^{5}$ cells.

\section{BLV+ Cows Have Reduced Proportions of Circulating T-Cell Populations In Vivo}

Although BLV most commonly infects B cells, previous research has suggested that T-cell immunity is also compromised in $\mathrm{BLV}^{+}$ cows (6). To investigate the circulating effector and memory $\mathrm{T}$-cell population in $\mathrm{BLV}^{+}$cows after $\mathrm{KLH}$ inoculation, we labeled freshly isolated PBMCs to measure CD45R0 expression on $\mathrm{CD}^{+}$, $\mathrm{CD}^{+}$, and $\gamma \delta^{+} \mathrm{T}$ cells. BLV ${ }^{+}$cows consistently exhibited lower
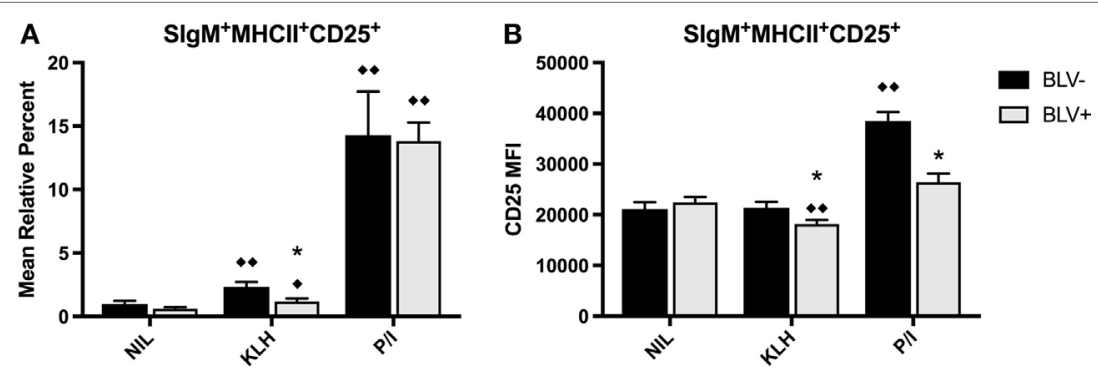

FIGURE 3 | B-cell activation in $\mathrm{BLV}^{+}$and $\mathrm{BLV}^{-}$cows after in vitro stimulation. PBMCs from BLV+ and BLV- cows were cultured in the presence of no (NIL), keyhole

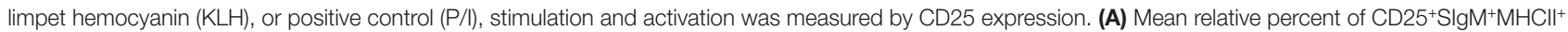
B cells. (B) CD25 mean fluorescence intensity on SlgM+MHCll+CD25+ B cells. ${ }^{*} p<0.05$ compared to BLV ${ }^{-},{ }^{*} p<0.05$ compared to nil, ${ }^{\star} p<0.1$ compared to nil. $n=8-9$ /group. Data represent the mean \pm SEM. 

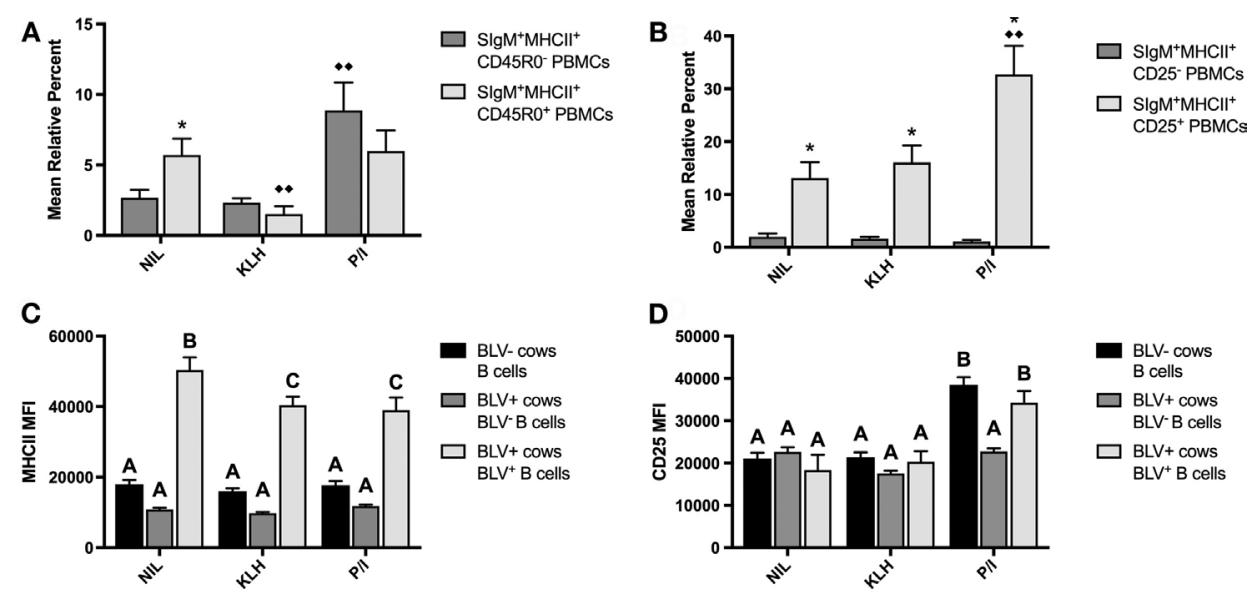

FIGURE 4 | BLV expression in vitro. PBMCs from BLV+ and BLV- cows were cultured in the presence of no (NIL), keyhole limpet hemocyanin (KLH), or positive

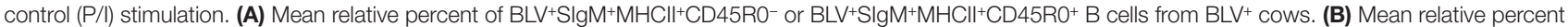

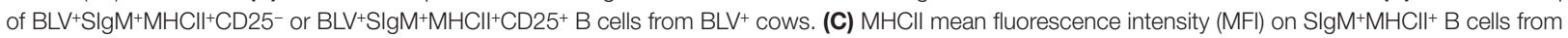

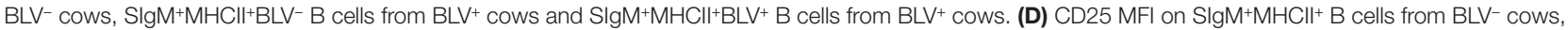
SlgM+MHCll+CD25+BLV- B cells from BLV ${ }^{+}$cows, and SlgM+MHCll+CD25+BLV+ B cells from BLV+ cows. ${ }^{*} p<0.05$ compared to CD45R0- or CD25- B cells, ${ }^{*} p<0.05$ compared to nil. Different letters denote significant differences. $n=8-9 /$ group. Data represent the mean \pm SEM.

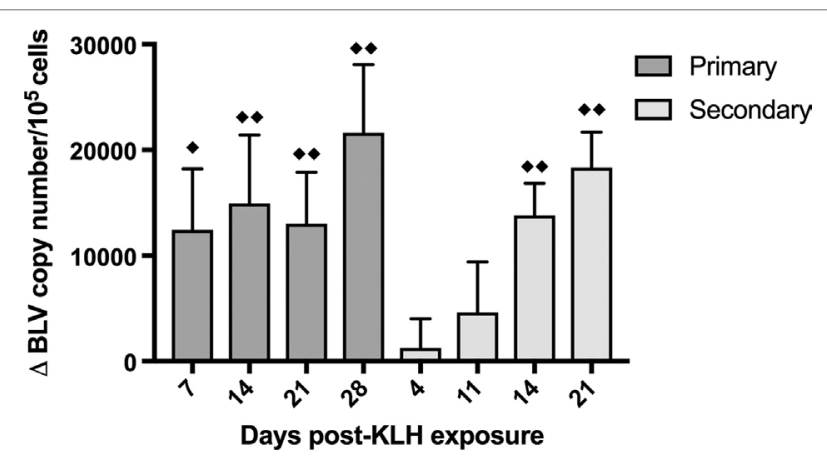

FIGURE 5 | Bovine leukemia virus (BLV) proviral load (PVL) in whole blood in $\mathrm{BLV}^{+}$cows. DNA was extracted from whole blood collected from BLV+ cows after keyhole limpet hemocyanin (KLH) inoculation and the BLV PVL was measured. The change in PVL after either primary (d0) or secondary (d56) $\mathrm{KLH}+$ DDA injection was determined. " $p<0.05$ compared to d0 (for primary) or to d56 (for secondary), $p<0.1$ compared to d0 or d56. $n=10$. Data represent the mean \pm SEM.

relative proportions of $\mathrm{CD}^{+}, \mathrm{CD}^{+}$, and $\gamma \delta^{+} \mathrm{T}$ cells $(p<0.05)$ (Figure 6D), although these did not change over time. However, both $\mathrm{CD} 4^{+} \mathrm{CD} 45 \mathrm{R} 0^{+}$(Figure 6A) and $\mathrm{CD} 8^{+} \mathrm{CD} 45 \mathrm{R} 0^{+}$(Figure 6B) T-cell populations significantly responded to primary and secondary KLH inoculations $(p<0.05)$ : both populations increased after inoculation, although there was no difference between $\mathrm{CD}^{+} \mathrm{CD} 45 \mathrm{R}^{+}(p=0.3816)$ or $\mathrm{CD}^{+} \mathrm{CD} 45 \mathrm{R}^{+}(p=0.4237)$ populations in $\mathrm{BLV}^{+}$and $\mathrm{BLV}^{-}$cows. In contrast to classical $\mathrm{T}$ cells, the $\gamma \delta^{+} \mathrm{CD} 45 \mathrm{R} 0^{+}$population did not significantly change over time after KLH exposure; however, $\mathrm{BLV}^{+}$cows demonstrated a greatly diminished $\gamma \delta^{+} \mathrm{CD} 450^{+} \mathrm{T}$-cell population $(p<0.0001)$ (Figure 6C). These data indicate that while BLV infection does not appear to affect the classical effector/memory T-cell compartment, BLV infection may negatively impact the $\gamma \delta$ effector/memory T-cell compartment.

\section{T Cells from BLV+ Cows Produce More IL4 after Stimulation In Vitro}

In addition to investigate the circulating effector/memory T-cell compartment, we examined whether $\mathrm{T}$ cells from $\mathrm{BLV}^{+}$cows generated IFN $\gamma$ or IL4 in response to stimulation in vitro. While in vitro T-cell activation was measured on $\mathrm{d} 7,14,56,67$, and 77 , there was no difference between time points; thus, the IFN $\gamma$ data presented in Figure 7 is from d56. Overall, KLH stimulation failed to increase the proportion of IFN $\gamma^{+}$cells in any T-cell subset and actually decreased the proportion of IFN $\gamma^{+} \mathrm{CD}^{+} \mathrm{T}$ cells from both $\mathrm{BLV}^{+}$and $\mathrm{BLV}^{-}$cows. There was no overall difference between $\mathrm{BLV}^{+}$and $\mathrm{BLV}^{-}$cows in the proportion of IFN $\gamma^{+} \mathrm{CD}^{+}$ $\mathrm{T}$ cells $(p=0.150)$ (Figure $7 \mathrm{~A})$ or $\mathrm{CD}^{+} \mathrm{T}$ cells $(p=0.112)$ (Figure 7B). Unlike classical T cells, $\gamma \delta^{+} \mathrm{T}$-cell IFN $\gamma$ production was significantly higher in $\mathrm{BLV}^{+}$cows $(p=0.0007)$ (Figure $7 \mathrm{C}$ ).

We also measured the IFN $\gamma$ MFI as a measure of reactivity to in vitro stimulation. While there was no difference in IFN $\gamma$ MFI from $\mathrm{CD}^{+}$or $\gamma \delta^{+} \mathrm{T}$ cells between $\mathrm{BLV}^{+}$and $\mathrm{BLV}^{-}$cows (data not shown), BLV status did have a significant effect on IFN $\gamma$ MFI from $\mathrm{CD}^{+} \mathrm{T}$ cells $(p=0.044)$ : reactive $\mathrm{CD}^{+} \mathrm{T}$ cells from $\mathrm{BLV}^{+}$ cows were actually producing more IFN $\gamma$ than reactive $\mathrm{CD} 8^{+}$ $\mathrm{T}$ cells from $\mathrm{BLV}^{-}$cows (Figure 7D).

We also studied IL4 production by T-cell subsets in $\mathrm{BLV}^{+}$cows. Similar to the in vitro IFN $\gamma$ results, in vitro IL4 production was not different between time points; thus, the IL4 data presented in Figure 8 are from d77. Surprisingly, in vitro IL4 production was not similar to what was observed with in vitro IFN $\gamma$ production. BLV status had a significant or trending significant effect on the proportion of IL4-producing cells within $\mathrm{CD}^{+}(p=0.0009)$, $\mathrm{CD}^{+}(p=0.0006)$, and $\gamma \delta^{+} \mathrm{T}$-cell $(p=0.0879)$ populations. In 


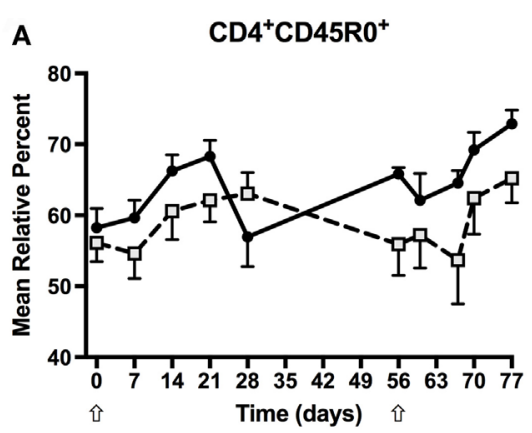

C

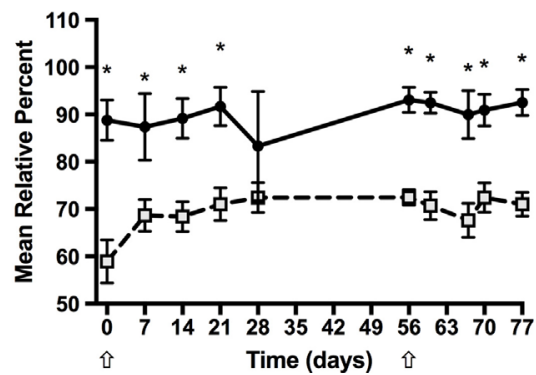

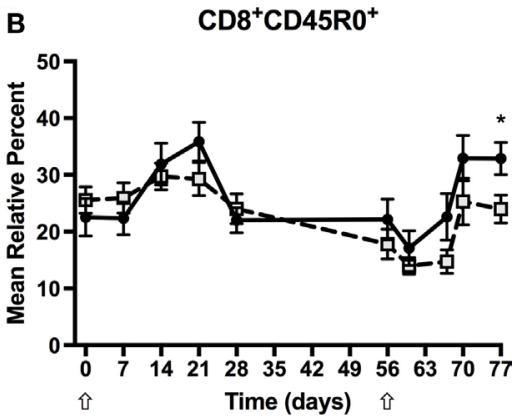

D
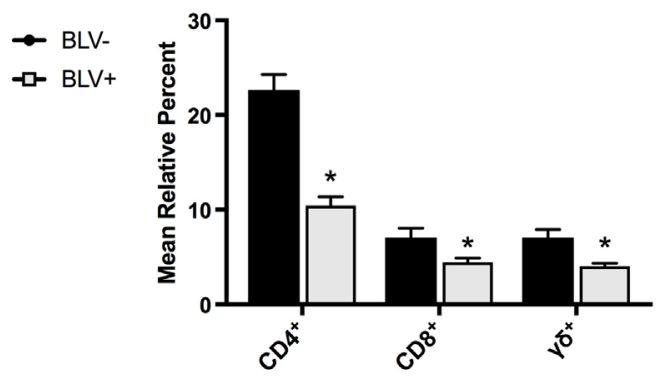

FIGURE 6 | Circulating T-cell populations in BLV+ and BLV- cows. Freshly isolated PBMCs from BLV+ and BLV- cows were immunostained to characterize the circulating T-cell population. (A) Mean relative percent of $\mathrm{CD} 45 \mathrm{RO} 0^{+} \mathrm{CD} 4^{+} \mathrm{T}$ cells. (B) Mean relative percent of $\mathrm{CD} 45 \mathrm{RO} \mathrm{O}^{+} \mathrm{CD} 8^{+} \mathrm{T}$ cells. (C) Mean relative percent of $\mathrm{CD} 45 \mathrm{RO}^{+} \gamma \delta^{+} \mathrm{T}$ cells. (D) Mean relative percent of $\mathrm{CD} 4^{+}, \mathrm{CD} 8^{+}$, and $\gamma \delta^{+} \mathrm{T}$-cell populations on d0. ${ }^{*} p<0.05 . n=6-9 /$ group. Arrows denote keyhole limpet hemocyanin inoculations. Data represent the mean \pm SEM.
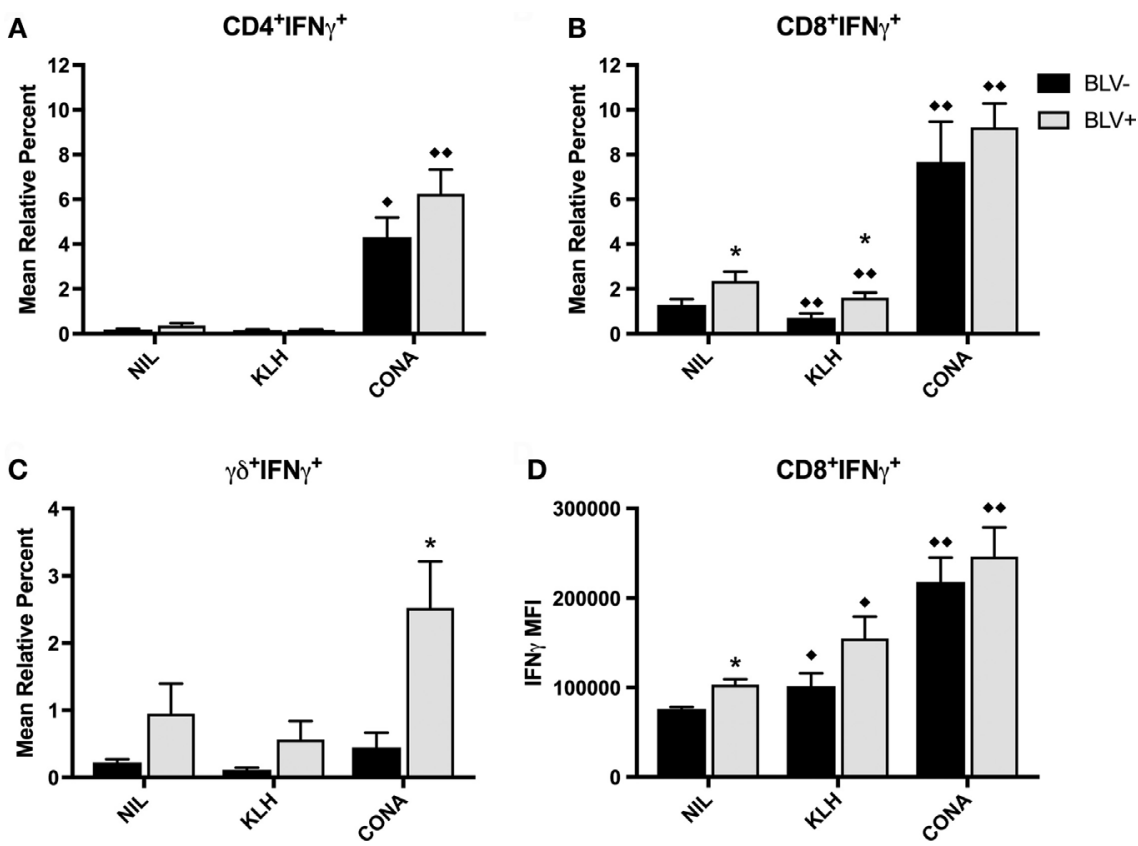

FIGURE 7 | IFN $\gamma$ production by T cells from BLV+ and BLV- cows. PBMCs from BLV+ and BLV- cows were cultured with no (NIL), keyhole limpet hemocyanin (KLH), or positive control (CONA) stimulation and IFN $\gamma$ production by T-cell subsets was measured. (A) Mean relative percent of IFN $\gamma^{+} \mathrm{CD} 4^{+} \mathrm{T}$ cells. (B) Mean relative percent of IFN $\gamma^{+} \mathrm{CD} 8^{+} T$ cells. (C) Mean relative percent of IFN $\gamma^{+} \gamma \delta^{+} T$ cells. (D) IFN $\gamma$ mean fluorescence intensity on $\mathrm{CD} 8^{+}$IFN $\gamma^{+} T$ cells. ${ }^{*} p<0.05$ compared to BLV-, $" p<0.05$ compared to nil, $" p<0.1$ compared to nil. $n=8-9 /$ group. Data represent the mean \pm SEM. 

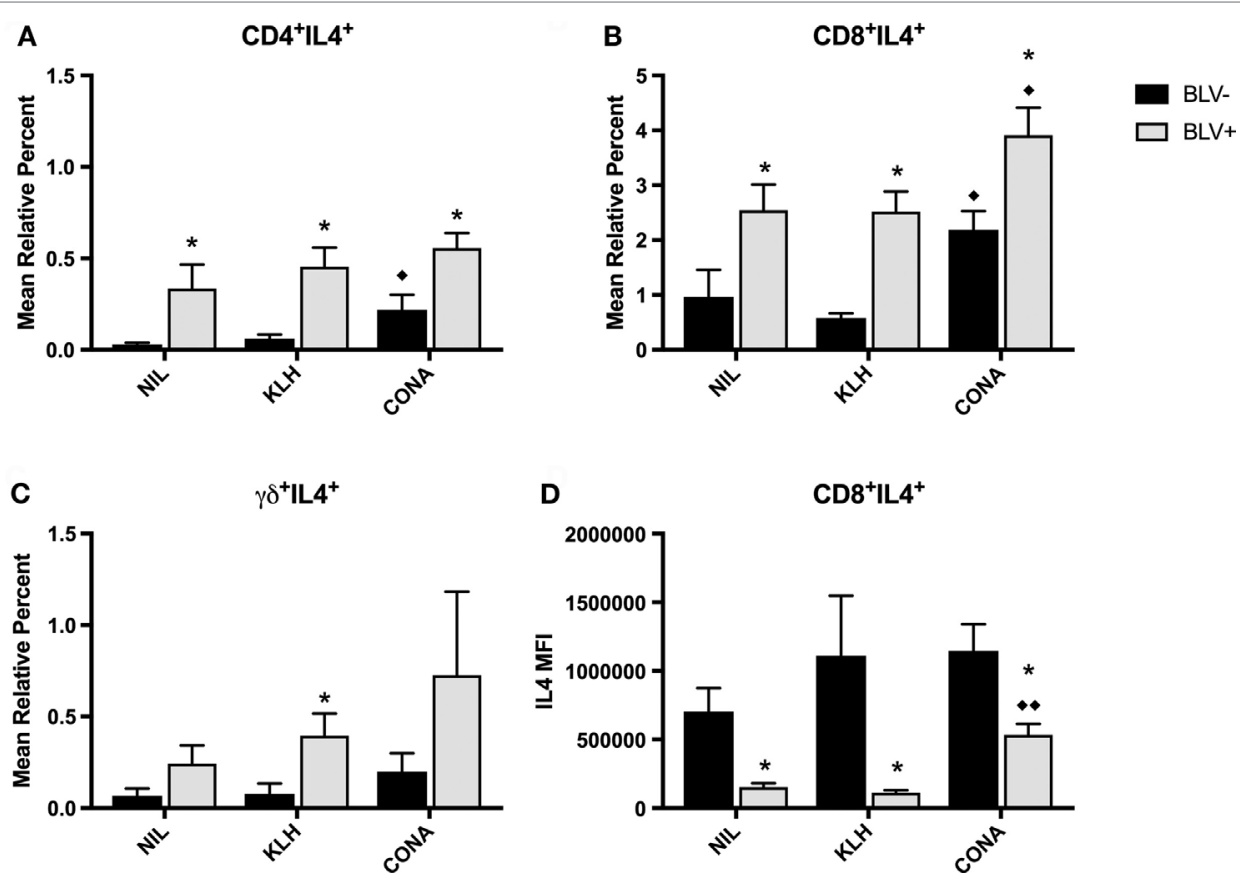

FIGURE 8 | IL4 production by T cells from BLV+ and BLV- cows. PBMCs from BLV+ and BLV- cows were cultured with no (NIL), keyhole limpet hemocyanin (KLH), or positive control (CONA) stimulation and IL 4 production by T-cell subsets was measured. (A) Mean relative percent of IL $4^{+} C D 4^{+} T$ cells. (B) Mean relative percent of IL4 $4^{+} C D 8^{+} T$ cells. (C) Mean relative percent of IL4+ ${ }^{+} \gamma \delta^{+} T$ cells. (D) IL4 mean fluorescence intensity on CD8+IL4+ $T$ cells. ${ }^{*} p<0.05$ compared to BLV-, "* $p<0.05$ compared to nil, $\bullet<0.1$ compared to nil. $n=7-8 /$ group. Data represent the mean \pm SEM.

all three T-cell populations, $\mathrm{BLV}^{+}$cows consistently exhibited a higher proportion of IL4-producing T cells (Figures 8A-C). However, reactive $\mathrm{CD}^{+} \mathrm{T}$ cells from $\mathrm{BLV}^{+}$cows actually exhibited lower IL4 expression in comparison to reactive CD8 ${ }^{+} \mathrm{T}$ cells from $\mathrm{BLV}^{-}$cows $(p<0.0001)$ (Figure 8D). The IL4 MFI from CD4 ${ }^{+}$ and $\gamma \delta^{+} \mathrm{T}$ cells was not different between $\mathrm{BLV}^{+}$and $\mathrm{BLV}^{-}$cows (data not shown). Taken together, these results imply that $\mathrm{T}$ cells from $\mathrm{BLV}^{+}$cows are capable of producing both IFN $\gamma$ and IL4 after in vitro cell culture; however, the balance in $\mathrm{BLV}^{+}$cows may favor a greater proportion of IL4-producing $\mathrm{T}$ cells.

\section{DISCUSSION}

In this study, we investigated how $\mathrm{BLV}^{+}$dairy cows respond to both a primary immune stimulation and a secondary immune stimulation. After exposing $\mathrm{BLV}^{+}$and $\mathrm{BLV}^{-}$cows to a noninfectious antigen $(\mathrm{KLH})$, both $\mathrm{B}$ - and $\mathrm{T}$-cell responses were tracked over a 3-month period to measure both the primary and secondary immune responses. Alterations were observed in both $\mathrm{B}$ - and $\mathrm{T}$-cell immunities in $\mathrm{BLV}^{+}$cows relative to uninfected herdmates: $\mathrm{BLV}^{+}$cows produced lower titers of KLH-specific IgM after primary immune stimulation; exhibited fewer CD45R ${ }^{+}$ $\mathrm{B}$ cells, increased $\mathrm{CD} 5^{\mathrm{dim}+} \mathrm{B}$ cells with higher CD5 expression, reduced $\mathrm{CD} 5$ expression on $\mathrm{CD} 5^{\text {bright+ }} \mathrm{B}$ cells, and reduced $\mathrm{MHCII}$ surface expression on B cells in circulation; displayed reduced B-cell activation in vitro; and exhibited an increase in BLV PVL. In addition, $\mathrm{BLV}^{+}$cows demonstrated a reduced $\mathrm{CD} 45 \mathrm{R} 0^{+} \gamma \delta^{+}$ $\mathrm{T}$-cell population in the periphery and demonstrated a greater prevalence of IL4-producing $\mathrm{T}$ cells in vitro. Taken together, these results suggest that $\mathrm{BLV}^{+}$cows do have abnormal immune responses even upon a primary immune stimulation. Atypical immune responses may make $\mathrm{BLV}^{+}$cows more vulnerable to other infections of economic importance. This risk is readily apparent at first exposure to a novel antigen as well as after repeated exposure to a common vaccine (10).

Similar to results seen in previous studies $(10,11), \mathrm{BLV}^{+}$cows demonstrated less antigen-specific IgM after primary stimulation. Although $\mathrm{BLV}^{+}$cows produced equivalent levels of $\operatorname{IgM}$ after secondary stimulation, this appears to be the result of IgM levels declining in $\mathrm{BLV}^{-}$cows between primary and secondary stimulations. In contrast, no differences were observed in either IgG1 production or IgG2 production against KLH. While other studies have found altered IgG levels in $\operatorname{BLV}^{+}$cattle $(9,11)$, it is possible that any impairment of IgG production is only detectable after repeated antigen exposure. While IgG antibodies have higher affinity for antigens, IgM is particularly important during a primary immune response as the first secreted isotype and is especially important for activating complement, which provides critical protection against bacterial infections.

It was interesting to note that the overall circulating B-cell population in $\mathrm{BLV}^{+}$cows alone increased after both primary and secondary KLH stimulations. $30 \%$ of $\mathrm{BLV}^{+}$cattle develop $\mathrm{PL}$, which is characterized by a chronic, polyclonal expansion of B cells in peripheral blood (3). While the mechanisms by which BLV causes PL are not well understood, B-cell population dynamics are clearly dysregulated during polyclonal expansion 
(6). Because the prevalence of circulating B cells in $\mathrm{BLV}^{+}$cows did not remain elevated between primary and secondary stimulations, it suggests that the prevalence of circulating B cells in the periphery was the result of KLH+ DDA exposure. It was especially intriguing that the BLV PVL significantly increased over time after both the primary and secondary KLH inoculations. BLV primarily infects B cells (5) and prior research found that $66 \%$ of $\mathrm{CD}^{+} \mathrm{B}$ cells carried the provirus (16), so these results could indicate that $\mathrm{BLV}$-infected $\mathrm{B}$ cells proliferate in response to immune stimulation.

In addition to the total B-cell population, two subpopulations of circulating B cells were tracked. Although CD45R0 ${ }^{+} \mathrm{B}$ cells did not change over time, $\mathrm{BLV}^{+}$cows consistently demonstrated a substantial reduction in the prevalence of $\mathrm{CD} 45 \mathrm{R} 0^{+} \mathrm{B}$ cells. While CD45R0 expression is better characterized on $\alpha \beta$ T cells, its expression on B cells likely indicates either (1) a memory $\mathrm{B}$ cell or (2) a differentiating B cell that may become either a memory B cell or a plasma cell (17). The smaller CD45R0 ${ }^{+}$ $\mathrm{B}$-cell population in $\mathrm{BLV}^{+}$cows at all time points could indicate a deficiency in either developing or maintaining B-cell memory, which would be especially detrimental for any immune response dependent on antibody production. Another concerning result was that the overall $\mathrm{B}$-cell population, and the $\mathrm{CD} 5^{\mathrm{dim}+} \mathrm{B}$-cell population in particular, in $\mathrm{BLV}^{+}$cows had lower $\mathrm{MHCII}$ surface expression, which could also impair humoral immunity development that is required for isotype switching. Although in this study we did not observe reduced IgG1 or IgG2 antibody production in $\mathrm{BLV}^{+}$cows, this may be because we only tested a secondary antigen exposure. A previous study has found a reduced IgG2 antibody production in $\mathrm{BLV}^{+}$cows after repeated vaccination (9).

When examining the $\mathrm{CD}^{+} \mathrm{B}$-cell compartment, we detected two distinct $\mathrm{CD} 5^{+} \mathrm{B}$-cell populations, which we denoted $\mathrm{CD} 5^{\mathrm{dim}+}$ and $\mathrm{CD} 5^{\text {bright+ }}$. While bovine $\mathrm{B}$ cells have been found to contain both a $C D 5^{\text {dim }}$ population and a CD $5^{\text {bright }}$ population (18), most BLV studies have only focused on CD5 expression in total, where $\mathrm{CD}^{+} \mathrm{B}$ cells are the type of B cell that expands in PL cattle (5). However, we kept the $\mathrm{CD} 5^{\mathrm{dim}+}$ and $\mathrm{CD} 5^{\text {bright+ }} \mathrm{B}$-cell populations distinct because the two populations showed different kinetics after KLH inoculation and there were significant differences in these two cell populations between $\mathrm{BLV}^{+}$and $\mathrm{BLV}^{-}$cows. While the $\mathrm{CD}^{\mathrm{dim}+} \mathrm{B}$-cell population increased after $\mathrm{KLH}$ inoculation, the $\mathrm{CD}^{\text {bright+ }} \mathrm{B}$-cell population sharply declined. When comparing $\mathrm{BLV}^{+}$and $\mathrm{BLV}^{-}$cows, $\mathrm{BLV}^{+}$cows had an elevated $\mathrm{CD} 5^{\text {dim+ }}$ population, but the $\mathrm{CD} 5^{\text {bright+ }}$ populations were equivalent. Finally, while $\mathrm{CD}^{\mathrm{dim}+} \mathrm{B}$ cells from $\mathrm{BLV}^{+}$cows exhibited higher mean CD5 surface expression, CD5 ${ }^{\text {bright+ }} \mathrm{B}$ cells from $\mathrm{BLV}^{+}$cows exhibited lower mean CD5 surface expression. It is unclear what functional differences may exist between CD $5^{\text {dim+ }}$ and $\mathrm{CD} 5^{\text {bright+ }} \mathrm{B}$ cells. CD5 expression on B cells may be a lineage marker for innate-like B cells that produce natural IgM (19), but CD5 expression on B cells may also be induced after stimulation through the B-cell receptor (20), and it is possible that the $\mathrm{CD}^{\text {dim+ }}$ and $\mathrm{CD}^{\text {bright+ }}$ populations reflect these different patterns of CD5 expression. Our data suggests that the distinction is relevant in the context of BLV infection, but our study was unable elucidate the function of these distinct B-cell subtypes.
We also investigated how B cells responded to KLH stimulation in vitro. While $\mathrm{B}$ cells from both $\mathrm{BLV}^{+}$and $\mathrm{BLV}^{-}$cows showed a minor but significant increase in $\mathrm{CD} 25^{+} \mathrm{B}$ cells after KLH stimulation, the proportion of $\mathrm{CD}_{2} 5^{+} \mathrm{B}$ cells from $\mathrm{BLV}{ }^{+}$ cows was significantly lower. In addition to the relative percent of $\mathrm{CD}_{25} 5^{+} \mathrm{B}$ cells, CD25+ $\mathrm{B}$ cells from $\mathrm{BLV}^{+}$cows exhibited significantly lower CD25 surface expression after both KLH and $\mathrm{P} / \mathrm{I}$ stimulations, suggesting that $\mathrm{BLV}^{+}$cows display less antigen-specific or mitogenic B-cell activation when compared to healthy, $\mathrm{BLV}^{-}$cows. We also questioned whether $\mathrm{KLH}$ stimulation would induce BLV protein expression. While P/I stimulation induced BLV gp51 expression as expected (21), KLH stimulation did not. However, it was clear that BLV expression was most common in $\mathrm{CD}_{2} 5^{+} \mathrm{B}$ cells, indicating that BLV gp51 expression is related to B-cell activation. BLV expression was also related to different patterns of MHCII and CD25 surface expression. Under all culture conditions, BLV-expressing B cells had a dramatically increased MHCII surface expression, which was in contrast to MHCII expression observed on B cells ex vivo. Active BLV transcription is rarely detected ex vivo, while even short term in vitro culture can induce detectable BLV protein production (22), which suggests that the BLV protein expression is inducing elevated MHCII expression. In contrast, BLV expression did not affect CD25 surface expression in unstimulated or KLH-stimulated cultures. After P/I stimulation, CD25 surface expression increased only on $\mathrm{B}$ cells from $\mathrm{BLV}^{-}$cows or on BLV-expressing B cells from $\mathrm{BLV}^{+}$cows; the CD25 surface expression on $\mathrm{BLV}^{-} \mathrm{B}$ cells from $\mathrm{BLV}^{+}$cows remained unchanged. Overall, our B-cell culture experiments suggest that $\mathrm{B}$ cells from $\mathrm{BLV}^{+}$cows have a reduced responsiveness to antigenic and mitogenic stimulations and this reduced responsiveness is not necessarily dependent on active BLV protein expression.

While the potential effect of BLV infection on B cells is obvious, it is less clear how BLV infection affects the T-cell compartment, although T-cell irregularities have been previously observed (6). We measured the circulating CD45R $0^{+} \mathrm{T}$-cell populations to investigate effector/memory $\mathrm{T}$ cells (23). Both the $\mathrm{CD} 4^{+}$and $\mathrm{CD}^{+} \mathrm{CD}^{+} 5 \mathrm{R}^{+} \mathrm{T}$-cell populations increased over time after KLH+ DDA stimulation, although the abundance of the cell types was equivalent between $\mathrm{BLV}^{+}$and $\mathrm{BLV}^{-}$cows. While the $\gamma \delta^{+} \mathrm{CD} 45 \mathrm{R} 0^{+} \mathrm{T}$-cell population remained mostly constant after $\mathrm{KLH}+\mathrm{DDA}$ exposure, $\mathrm{BLV}^{+}$cows exhibited a large overall reduction in their $\gamma \delta^{+} \mathrm{CD} 45 \mathrm{R} 0^{+} \mathrm{T}$-cell population. Although $\gamma \delta^{+} \mathrm{CD} 45 \mathrm{R} 0^{+} \mathrm{T}$ cells are not a well-characterized cell population, CD45R0 expression likely indicates current or prior activation, although it is unclear whether this activation would be innate or adaptive or both (24).

We were also interested in investigating IFN $\gamma$ and IL4 productions in response to KLH stimulation in vitro. While we were unable to detect increased cytokine production in KLHstimulated cell culture, we found that both $\mathrm{CD}^{+}$and $\mathrm{CD}^{+}$ T-cell populations from $\mathrm{BLV}^{+}$and $\mathrm{BLV}^{-}$cows were equally responsive to positive control stimulation when measuring IFN $\gamma$ production. Similar to previous results (10), a significantly higher proportion of $\gamma \delta^{+}$T cells from $\mathrm{BLV}^{+}$cows produced IFN $\gamma$ in cell culture. Surprisingly, while the amount of IFN $\gamma$ produced 
by $\mathrm{CD}^{+}$and $\gamma \delta^{+} \mathrm{T}$ cells was not different between $\mathrm{BLV}^{+}$and $\mathrm{BLV}^{-}$cows, $\mathrm{CD}^{+} \mathrm{T}$ cells from $\mathrm{BLV}^{+}$cows did produce significantly higher amounts of IFN $\gamma$. When we similarly investigated IL4 production in vitro, we observed directly opposite results. $\mathrm{CD}^{+}$and $\mathrm{CD}^{+}{ }^{+}$-cell populations from $\mathrm{BLV}^{+}$cows contained higher proportions of IL4-producting cells under all cell culture conditions; conversely, $\gamma \delta^{+} \mathrm{T}$ cells produced IL4 in equivalent proportions between $\mathrm{BLV}^{+}$and $\mathrm{BLV}^{-}$cows. Finally, while $\mathrm{BLV}^{+}$ cows contained higher proportions of IL4-producing $\mathrm{CD}^{+}$ $\mathrm{T}$ cells in vitro, reactive $\mathrm{CD}^{+}$IL4-producing cells from $\mathrm{BLV}^{-}$ cows actually produced more IL4 under all culture conditions. This difference in IL4-producing cells versus IL4 expression on a per-cell basis could be a result of suppressed activation in $\mathrm{CD}^{+} \mathrm{T}$ cells from $\mathrm{BLV}^{+}$cows. While $\mathrm{BLV}^{+}$cows have a higher proportion of $\mathrm{CD}^{+} \mathrm{T}$ cells producing IL4, it is possible that BLV infection interferes with the degree of activation after $\mathrm{CD}^{+}$ $\mathrm{T}$ cell stimulation, although this was not observed with IFN $\gamma$ production in $\mathrm{CD}^{+} \mathrm{T}$ cells from $\mathrm{BLV}^{+}$cows. While IL4 production by $\mathrm{CD}^{+} \mathrm{T}$ cells in cattle is not well-studied, evidence from humans and mice suggest that $\mathrm{CD}^{+} \mathrm{T}$ cells may also be polarized based upon their cytokine secretion and that this cytokine secretion can contribute to the overall balance of a cell-mediated versus humoral immune response $(25,26)$.

While our experiment was unable to detect any differences in antigen-specific activation in T cells from $\mathrm{BLV}^{+}$cows, we did detect overall differences in circulating $\gamma \delta^{+} \mathrm{T}$ cells and in $\alpha \beta$ and $\gamma \delta^{+}$T-cell cytokine production in vitro. The considerable reduction in circulating $\mathrm{CD} 45 \mathrm{R} 0^{+} \gamma \delta^{+} \mathrm{T}$ cells in $\mathrm{BLV}^{+}$cows could suggest an impairment of effector or memory $\gamma \delta^{+} \mathrm{T}$ cells in $\mathrm{BLV}^{+}$cows; considering the hypothesized importance of $\gamma \delta^{+}$ $\mathrm{T}$ cells in bovine immunity (27), an impairment in this T-cell subtype could have serious consequences on both innate and adaptive immunities in cattle, including reduced responsiveness to vaccination and less immune protection from pathogens including Mycobacterium bovis and Leptospira borgpetersenii serovar Hardjo (28). Our in vitro experiments suggest that $\alpha \beta$ $\mathrm{T}$ cells in $\mathrm{BLV}^{+}$cattle could be more predisposed to produce IL4 as compared to $\alpha \beta$ T cells from healthy, $\mathrm{BLV}^{-}$cattle. If $\mathrm{BLV}^{+}$cattle immunity is more skewed toward IL4 over IFN $\gamma$ production, this could have profound effects upon infections that depend on Th1 versus Th2 immunity for effective pathogen clearance.

This study was conducted to investigate $\mathrm{B}$ - and $\mathrm{T}$-cell responses in $\mathrm{BLV}^{+}$cows to a primary and secondary antigenic immune challenge. While evidence demonstrates that BLV-infected cattle have atypical immunity in comparison to $\mathrm{BLV}^{-}$cows (6), little research has investigated whether $\mathrm{BLV}^{+}$cows would exhibit abnormal immune responses to a primary challenge, or if abnormal adaptive immunity in $\mathrm{BLV}^{+}$cattle was the cumulative effect of multiple antigenic challenges. Our study did find antigen-specific deficiencies in B-cell immunity during a primary immune response, indicating that BLV infection can interfere with antigen-specific immunity without many re-exposures to antigen. While we were unable to detect antigen-specific T-cell responses in vitro, we did detect abnormalities in circulating $\gamma \delta^{+}$
T cells in $\mathrm{BLV}^{+}$cows, as well as a potential bias for IL4-producing $\alpha \beta$ T cells. These data demonstrate that BLV infection can have a detectable impact on immune stimulation even upon a primary antigen exposure, which would likely mean that negative impacts of BLV infection on herd health could occur immediately upon a secondary infection.

\section{ETHICS STATEMENT}

All protocols were reviewed and approved by the Michigan State University Institutional Animal Use and Care Committee (AUF\# 04/15-061-00).

\section{AUTHOR CONTRIBUTIONS}

MF led the study and was involved in the study conception, design, execution, analysis, and interpretation of data. MF wrote the manuscript. KS contributed to study design, execution and interpretation of data, and manuscript editing. OB contributed to the study execution and analysis of data and wrote the PVL methods section of the manuscript. JW contributed to the study execution and manuscript editing. CD contributed to the study execution and manuscript editing. $\mathrm{PB}$ contributed to the study conception and design and manuscript editing. PC contributed to the study conception, design, and interpretation and manuscript editing.

\section{ACKNOWLEDGMENTS}

The authors gratefully acknowledge the contributions of other members of the Molecular Pathogenesis Laboratory: Hannah Dewald, Marie Wosny, Morgan Jernstadt, and Nikki Mallos. The authors would also like to thank Bradley Abramson from Michigan State University for his technical expertise. Finally, the authors would like to thank Kerry Nobis and the entire team at Nobis Dairy Farms for their invaluable assistance in completing this research. This work was supported by the United States Department of Agriculture and the National Institute of Food and Agriculture (2014-67015-21632, 2014-68004-21881, and 201667011-24713), Michigan AgBioResearch, the Michigan Alliance for Animal Agriculture and the Michigan Milk Producers Association.

\section{SUPPLEMENTARY MATERIAL}

The Supplementary Material for this article can be found online at http://journal.frontiersin.org/article/10.3389/fvets.2017.00112/ full\#supplementary-material.

FIGURE S1 | Gating strategy to determine CD5 $5^{\text {dim+ }}$ and CD5 $5^{\text {bright+ }}$ B cells. To identify $\mathrm{CD}^{+}{ }^{+}$dim and bright populations, the upper right quadrant was used to denote $\mathrm{CD}^{+}$cells. A rectangle gate was used to select CD5 $5^{\text {bright+ }}$ cells, and cells inside the quadrant gate and outside the rectangle gate were determined to be CD5 ${ }^{\text {dim+ }}$ cells. Representative plots are from fresh labeling on D56 and feature samples from representative $\mathrm{BLV}^{-}$and $\mathrm{BLV}^{+}$cows. 


\section{REFERENCES}

1. Gillet N, Florins A, Boxus M, Burteau C, Nigro A, Vandermeers F, et al. Mechanisms of leukemogenesis induced by bovine leukemia virus: prospects for novel anti-retroviral therapies in human. Retrovirology (2007) 4:18. doi:10.1186/1742-4690-4-18

2. Bartlett PC, Sordillo LM, Byrem TM, Norby B, Grooms DL, Swenson CL, et al. Options for the control of bovine leukemia virus in dairy cattle. J Am Vet Med Assoc (2014) 244:914-22. doi:10.2460/javma.244.8.914

3. Kabeya H, Ohashi K, Onuma M. Host immune responses in the course of bovine leukemia virus infection. J Vet Med Sci (2001) 63:703-8. doi:10.1292/ jvms.63.703

4. Bartlett PC, Norby B, Byrem TM, Parmelee A, Ledergerber JT, Erskine RJ. Bovine leukemia virus and cow longevity in Michigan dairy herds. J Dairy Sci (2013) 96:1591-7. doi:10.3168/jds.2012-5930

5. Meirom R, Moss S, Brenner J. Bovine leukemia virus-gp51 antigen expression is associated with CD5 and IgM markers on infected lymphocytes. Vet Immunol Immunopathol (1997) 59:113-9. doi:10.1016/S0165-2427(97) 00056-1

6. Frie MC, Coussens PM. Bovine leukemia virus: a major silent threat to proper immune responses in cattle. Vet Immunol Immunopathol (2015) 163:103-14. doi:10.1016/j.vetimm.2014.11.014

7. Emanuelson U, Scherling K, Pettersson H. Relationships between herd bovine leukemia-virus infection status and reproduction, disease incidence, and productivity in Swedish Dairy Herds. Prev Vet Med (1992) 12:121-31. doi:10.1016/0167-5877(92)90075-Q

8. Trainin Z, Brenner J, Meirom R, Ungar-Waron H. Detrimental effect of bovine leukemia virus $(\mathrm{BLV})$ on the immunological state of cattle. Vet Immunol Immunopathol (1996) 54:293-302. doi:10.1016/S0165-2427(96)05706-6

9. Erskine RJ, Bartlett PC, Sabo KM, Sordillo LM. Bovine leukemia virus infection in dairy cattle: effect on serological response to immunization against J5 Escherichia coli bacterin. Vet Med Int (2011) 2011:915747. doi: $10.4061 / 2011 / 915747$

10. Frie MC, Sporer KR, Wallace JC, Maes RK, Sordillo LM, Bartlett PC, et al. Reduced humoral immunity and atypical cell-mediated immunity in response to vaccination in cows naturally infected with bovine leukemia virus. Vet Immunol Immunopathol (2016) 182:125-35. doi:10.1016/j. vetimm.2016.10.013

11. Puentes R, De Brun L, Algorta A, Da Silva V, Mansilla F, Sacco G, et al. Evaluation of serological response to foot-and-mouth disease vaccination in BLV infected cows. BMC Vet Res (2016) 12:119. doi:10.1186/s12917-016-0749-x

12. Panei CJ, Takeshima SN, Omori T, Nunoya T, Davis WC, Ishizaki H, et al. Estimation of bovine leukemia virus (BLV) proviral load harbored by lymphocyte subpopulations in BLV-infected cattle at the subclinical stage of enzootic bovine leucosis using BLV-CoCoMo-qPCR. BMC Vet Res (2013) 9:95. doi:10.1186/1746-6148-9-95

13. Nguyen TK, Koets AP, Santema WJ, van Eden W, Rutten VP, Van Rhijn I. The mycobacterial glycolipid glucose monomycolate induces a memory $\mathrm{T}$ cell response comparable to a model protein antigen and no B cell response upon experimental vaccination of cattle. Vaccine (2009) 27:4818-25. doi:10.1016/j. vaccine.2009.05.078

14. Jimba M, Takeshima SN, Matoba K, Endoh D, Aida Y. BLV-CoCoMo-qPCR: quantitation of bovine leukemia virus proviral load using the CoCoMo algorithm. Retrovirology (2010) 7:91. doi:10.1186/1742-4690-7-91
15. Jimba M, Takeshima SN, Murakami H, Kohara J, Kobayashi N, Matsuhashi T, et al. BLV-CoCoMo-qPCR: a useful tool for evaluating bovine leukemia virus infection status. BMC Vet Res (2012) 8:167. doi:10.1186/1746-6148-8-167

16. Mirsky ML, Olmstead CA, Da Y, Lewin HA. The prevalence of proviral bovine leukemia virus in peripheral blood mononuclear cells at two subclinical stages of infection. J Virol (1996) 70:2178-83.

17. McHeyzer-Williams LJ, McHeyzer-Williams MG. Antigen-specific memory B cell development. Annu Rev Immunol (2005) 23:487-513. doi:10.1146/ annurev.immunol.23.021704.115732

18. Stabel JR, Khalifeh MS. Differential expression of CD5 on B lymphocytes in cattle infected with Mycobacterium avium subsp. paratuberculosis. Vet Immunol Immunopathol (2008) 126:211-9. doi:10.1016/j.vetimm.2008.07.004

19. Carsetti R, Rosado MM, Wardmann H. Peripheral development of B cells in mouse and man. Immunol Rev (2004) 197:179-91. doi:10.1111/j.0105-2896.2004.0109.x

20. Haas KM, Estes DM. Activation of bovine B cells via surface immunoglobulin M cross-linking or CD40 ligation results in different B-cell phenotypes. Immunology (2000) 99:272-8. doi:10.1046/j.1365-2567.2000.00962.x

21. Jensen WA, Wicks-Beard BJ, Cockerell GL. Inhibition of protein kinase C results in decreased expression of bovine leukemia virus. J Virol (1992) 66:4427-33.

22. Florins A, Gillet N, Asquith B, Boxus M, Burteau C, Twizere JC, et al. Cell dynamics and immune response to BLV infection: a unifying model. Front Biosci (2007) 12:1520-31. doi:10.2741/2165

23. Farber DL, Yudanin NA, Restifo NP. Human memory T cells: generation, compartmentalization and homeostasis. Nat Rev Immunol (2014) 14:24-35. doi:10.1038/nri3567

24. De Maria R, Fais S, Silvestri M, Frati L, Pallone F, Santoni A, et al. Continuous in vivo activation and transient hyporesponsiveness to TcR/CD3 triggering of human gut lamina propria lymphocytes. Eur J Immunol (1993) 23:3104-8. doi:10.1002/eji.1830231209

25. Betts RJ, Kemeny DM. CD8+ T cells in asthma: friend or foe? Pharmacol Ther (2009) 121:123-31. doi:10.1016/j.pharmthera.2008.09.001

26. Kalinski P, Nakamura Y, Watchmaker P, Giermasz A, Muthuswamy R, Mailliard RB. Helper roles of NK and CD8+ T cells in the induction of tumor immunity. Polarized dendritic cells as cancer vaccines. Immunol Res (2006) 36:137-46. doi:10.1385/IR:36:1:137

27. Guzman E, Price S, Poulsom H, Hope J. Bovine gammadelta T cells: cells with multiple functions and important roles in immunity. Vet Immunol Immunopathol (2012) 148:161-7. doi:10.1016/j.vetimm.2011.03.013

28. Baldwin CL, Telfer JC. The bovine model for elucidating the role of gammadelta $\mathrm{T}$ cells in controlling infectious diseases of importance to cattle and humans. Mol Immunol (2015) 66:35-47. doi:10.1016/j.molimm.2014.10.024

Conflict of Interest Statement: The authors declare no conflict of interest. NorthStar Cooperative is a for-profit animal agriculture diagnostic company and conducted all diagnostic testing for this study free of charge in exchange for biological samples.

Copyright (C) 2017 Frie, Sporer, Benitez, Wallace, Droscha, Bartlett and Coussens. This is an open-access article distributed under the terms of the Creative Commons Attribution License (CC BY). The use, distribution or reproduction in other forums is permitted, provided the original author(s) or licensor are credited and that the original publication in this journal is cited, in accordance with accepted academic practice. No use, distribution or reproduction is permitted which does not comply with these terms. 